\title{
Simple and Practicable Methods for the Determination of Astemizole in Pharmaceuticals using Bromate-Bromide and Two Dyes
}

\author{
Paregowda Nagegowda and Kanakapura Basavaiah*
}

Department of Chemistry, University of Mysore, Manasagangotri, Mysore - 570 006, India

\begin{abstract}
Um método titrimétrico e dois espectrofotométricos, simples e sensíveis, são descritos para a determinação de astemizola (AST) em drogas comerciais e formulações. Os métodos usam a mistura brometo-bromato e dois pigmentos, laranja de metila e índigo carmim. Na titrimetria (Método A), astemizola é tratada com uma mistura ácida de brometo-bromato em excesso conhecido e depois do término completo da reação de bromatação, o excesso de bromo é reversamente titulado iodometricamente. Nos métodos espectrofotométricos, o excesso de bromo é estimado após o tratamento com uma quantia determinada de laranja de metila (Método B) ou índigo carmim (Metodo C), e as mudanças de absorbância medidas em 520 e 610 nm, respectivamente. Em todos os métodos, a quantidade de bromato reagido corresponde à quantidade na droga. O método tritrimetrico é aplicável na faixa de 4-16 mg e os cálculos são feitos numa relação 1:0,666 (AST:bromato). Nos espectrofotométricos, a curva de calibração é linear entre 0,5 e 4,0 $\mu \mathrm{g} \mathrm{mL}$ (Método B) e entre 1,25 e $12,5 \mu \mathrm{g} \mathrm{mL}$ (Método C), com valores de absortividade molar de $6,6 \times 10^{4} \mathrm{~L} \mathrm{~mol}^{-1} \mathrm{~cm}^{-1}$ e 2,1x10 $\mathrm{L} \mathrm{mol}^{-1}$ $\mathrm{cm}^{-1}$, respectivamente. Os limites de detecção e quantificação são apresentados para os Métodos B e C. A avaliação estatística foi examinada pela precisão da determinação intra- e inter-diária. Os métodos são aplicáveis na determinação de AST em cápsulas e xaropes, e os resultados são concordantes com os apresentados em rótulo. A exatidão e confiabilidade dos métodos foram testadas pela determinação paralela por um método de referência, com limite de confiança de $95 \%$ para valores t-Student e F-Student, e por estudos de recuperação por adição padrão.
\end{abstract}

One titrimetric and two spectrophotometric methods, which are simple and sensitive, are described for the determination of astemizole (AST) in bulk drug and formulations. The methods use bromatebromide mixture and two dyes, methyl orange and indigo carmine. In titrimetry (Method A), astemizole is treated with a known excess of bromate-bromide mixture in acid medium and after the bromination reaction is ensured to be complete, the residual bromine is back-titrated iodometrically. In spectrophotometric methods, the excess of bromine is estimated by treating it with a fixed amount of either methyl orange (Method B) or indigo carmine (Method C) and measuring the change in absorbance either at 520 or 610 $\mathrm{nm}$. In all the methods, the amount of bromate reacted corresponds to the drug content. Titrimetric method is applicable over 4-16 mg range and the calculations are based on a 1:0.666 (AST: bromate) reacting ratio. In spectrophotometry, the calibration graph is found to be linear over $0.5-4.0 \mu \mathrm{g} \mathrm{mL}^{-1}$ (Method B) and $1.25-12.5 \mu \mathrm{g} \mathrm{mL}^{-1}$ (Method C) with molar absorptivity values of $6.6 \times 10^{4} \mathrm{~L} \mathrm{~mol}^{-1} \mathrm{~cm}^{-1}$ and $2.1 \times 10^{4} \mathrm{~L}$ $\mathrm{mol}^{-1} \mathrm{~cm}^{-1}$, respectively. The limits of detection and quantification are reported for methods $\mathrm{B}$ and $\mathrm{C}$. The statistical evaluation of the methods was examined by determining intra-day and inter-day precision. The methods were applied to the determination of AST in tablets and syrups and the results were found to agree well with the label claim. The accuracy and reliability of the methods were further ascertained by parallel determination by a reference method and by calculating the Student's t-value and F-value at the $95 \%$ confidence level, and by recovery studies using standard addition technique.

Keywords: astemizole determination, titrimetry, spectrophotometry, dosage forms

\section{Introduction}

Astemizole (AST) is chemically 1-(4-fluorobenzyl2-\{[1-(4-methoxyphenethylethyl)-4-piperidyl] amino $\}-$

* e-mail: basavaiahk@yahoo.co.in benzimidazole. It is a potent and a long acting new $\mathrm{H}_{1}$ antihistamine used to treat symptoms of allergic disorders. It belongs to new class of drugs with few central or antimuscarinic effects. ${ }^{1,2}$ Currently, AST and its pharmaceutical dosage forms are not found in any pharmacopoeia. However, an analytical profile including 
elemental analysis, radio immuno assays and high performance liquid chromatographic determination has been reported. ${ }^{1}$ Only a few methods have been developed for the determination of AST in biological fluids and pharmaceutical dosage forms. The detection and determination of plasma protein-bound AST as a part of bioavailability studies has been carried out by thin layer chromatography. ${ }^{3}$ Woestenborghs et al. ${ }^{4}$ have reported the simultaneous determination of AST and its demethylated metabolite in human plasma and animal tissue by HPLC. The drug and its metabolites in plasma have been determined by radio immuno assay ${ }^{5}$ procedures.

One of the first reports ${ }^{6}$ on the determination of AST in pharmaceutical dosage forms consists of application of five techniques, non-aqueous titrimetry, TLC, HPLC, UV spectrophotometry and ion-pair based visible spectrophotometry. In addition, several techniques such as UV and derivative UV spectrophotometry, ${ }^{7} \mathrm{HPLC}^{8-10}$ and spectrofluorimetry ${ }^{11}$ have been used for the determination of the drug in dosage forms. Several visible spectrophotometric methods based on redox, ${ }^{12}$ complex formation, ${ }^{13,14}$ ion-pair, ${ }^{6,11,12,15,16}$ charge transfer complexation ${ }^{17}$ and ternary complexation ${ }^{18}$ reactions have been reported for the assay of AST.

The only reported titrimetric method ${ }^{6}$ employs a nonaqueous medium and is applicable for $250-650 \mathrm{mg}$ range. Many of the visible spectrophotometric methods found in the literature suffer from drawbacks such as a heating ${ }^{13}$ or extraction step, ${ }^{6,11,12,15,16}$ or low sensitivity. ${ }^{14,15,17}$ Titrimetry and spectrophotometry are well established techniques, and owing to their speed, selectivity, reduced implementation costs and versatility of application, they can be considered to be advantageous alternatives to sophisticated and expensive techniques normally used in pharmaceutical analysis. The present work is aimed at developing titrimetric and spectrophotometric methods that would overcome many of the problems encountered in the existing methods. This work describes, one titrimetric and two spectrophotometric methods for the determination of AST in bulk drug and in dosage forms based on bromination reaction using bromatebromide mixture and by employing two dyes. The methods are simple, accurate and easy to apply to routine use.

\section{Experimental}

\section{Apparatus}

A Systronics Model 106 digital spectrophotometer provided with $1 \mathrm{~cm}$ matched quartz cells was used for absorbance measurements.

\section{Materials}

All chemicals used were of analytical reagent grade and distilled water was used to prepare all solutions.

\section{Bromate-bromide mixture}

A $5 \mathrm{mmol} \mathrm{L}^{-1} \mathrm{KBrO}_{3} 50 \mathrm{mmol} \mathrm{L}^{-1} \mathrm{KBr}$ solution was prepared by dissolving accurately weighed $418 \mathrm{mg}$ of $\mathrm{KBrO}_{3}$ (Sarabhai M Chemicals, Baroda, India) and $3 \mathrm{~g}$ of $\mathrm{KBr}$ (Qualigens India Ltd. India) in water and diluting to the mark in a $500 \mathrm{~mL}$ calibrated flask and this solution was used in titrimetric work. For use in spectrophotometric study, a $1000 \mu \mathrm{g} \mathrm{mL}^{-1} \mathrm{KBrO}_{3}$ solution containing a large excess of $\mathrm{KBr}$ was prepared by dissolving $100 \mathrm{mg}$ of $\mathrm{KBrO}_{3}$ and $1 \mathrm{~g}$ of $\mathrm{KBr}$ in water and diluting to the mark in a 100 $\mathrm{mL}$ calibrated flask. This was diluted stepwise to get $10 \mu \mathrm{g}$ $\mathrm{mL}^{-1}$ and $30 \mu \mathrm{g} \mathrm{mL}^{-1}$ bromate solutions for use in Method $\mathrm{B}$ and Method $\mathrm{C}$, respectively.

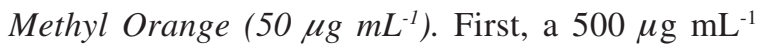
solution was prepared by dissolving $59 \mathrm{mg}$ of dye (S.d. Fine Chem, India, dye content $85 \%$ ) in water and diluting to the mark in a $100 \mathrm{~mL}$ calibrated flask and filtered. This was diluted 10-fold to obtain a working concentration of $50 \mu \mathrm{g} \mathrm{mL}^{-1}$.

Indigo carmine $\left(200 \mu \mathrm{g} \mathrm{mL}^{-1}\right)$. A $1000 \mu \mathrm{g} \mathrm{mL}^{-1}$ solution was first prepared by dissolving $111 \mathrm{mg}$ of dye (S.d. Fine Chem, Mumbai, India, dye content 90\%) in water and diluting to the mark in a $100 \mathrm{~mL}$ calibrated flask and filtered. The stock solution was diluted appropriately to get $200 \mu \mathrm{g} \mathrm{mL}^{-1}$ dye solution with water.

Sodium thiosulphate $\left(0.03 \mathrm{~mol} \mathrm{~L}^{-1}\right)$. About $8 \mathrm{~g}$ of chemical (Sharabhai M Chemicals, Baroda, India) was dissolved in $1 \mathrm{~L}$ water and the solution was standardized ${ }^{26}$ iodometrically using a pure sample of potassium dichromate.

Hydrochloric acid $\left(5 \mathrm{~mol} \mathrm{~L}^{-1}\right)$. A $112 \mathrm{~mL}$ volume of concentrated acid (S.d. Fine Chem, Mumbai, India, Sp gr 1.18) was diluted to $250 \mathrm{~mL}$ with water and mixed well.

Potassium iodide (10\%). Prepared by dissolving $25 \mathrm{~g}$ of chemical (Qualigens Fine Chemicals, India) in $250 \mathrm{~mL}$ of water.

Starch indicator (1\%). One g of starch paste made in water was slowly poured into $100 \mathrm{~mL}$ boiling water, boiled for $1 \mathrm{~min}$ and cooled.

Astemizole standard solution. A $2 \mathrm{mg} \mathrm{mL}^{-1}$ standard drug solution was prepared by dissolving $500 \mathrm{mg}$ of pharmaceutical grade astemizole (received as gift from UCB India Ltd, Mumbai, India) in $25 \mathrm{~mL}$ of glacial acetic acid and diluting to the mark with water in a $250 \mathrm{~mL}$ calibrated flask and was used in titrimetry. This solution was then diluted with water to get $10 \mu \mathrm{g} \mathrm{mL}^{-1}$ and 
$25 \mu \mathrm{g} \mathrm{mL}^{-1}$ solutions for use in Method B and Method C, respectively.

\section{Procedure}

Visual titrimetry (Method A). A $10 \mathrm{~mL}$ aliquot of pure drug solution containing 4-16 mg of AST was accurately transferred into a $100 \mathrm{~mL}$ Erlenmeyer flask. Ten $\mathrm{mL}$ of bromate-bromide solution ( $5 \mathrm{mmol} \mathrm{L}^{-1}$ w.r.t $\mathrm{KBrO}_{3}$ ) was transferred to the flask by means of a pipette. The solution was acidified by adding $7 \mathrm{~mL}$ of $2 \mathrm{~mol} \mathrm{~L}^{-1}$ hydrochloric acid. The flask was stoppered, the content mixed well and kept aside for 15 min with occasional swirling. The stopper was then washed with $5 \mathrm{~mL}$ of water and $5 \mathrm{~mL}$ of $10 \%$ potassium iodide solution was added to the flask. The liberated iodine was titrated with $0.03 \mathrm{~mol} \mathrm{~L}^{-1}$ sodium thiosulphate to a starch end point. A blank titration was run under identical conditions.

The amount of drug in the measured aliquot was calculated from:

$\mathrm{mg}=\frac{(\mathrm{B}-\mathrm{S}) \mathrm{M}_{\mathrm{w}} \mathrm{R}}{\mathrm{x}}$

where $\mathrm{B}=$ volume of thiosulphate consumed in the blank titration in $\mathrm{mL} ; \mathrm{S}=$ volume of thiosulphate consumed in the sample titration in $\mathrm{mL} ; \mathrm{M}_{\mathrm{w}}=$ relative molecular mass of drug; $\mathrm{R}=$ concentration of bromate solution in $\mathrm{mol} \mathrm{L}^{-1} ; \mathrm{x}=$ number of moles of bromate reacting with each mole of drug.

Spectrophotometry with methyl orange (Method B). Different aliquots $(0.5-4.0 \mathrm{~mL})$ of $10 \mu \mathrm{g} \mathrm{mL}^{-1}$ AST solution were accurately measured into a series of $10 \mathrm{~mL}$ calibrated flasks and the total volume was adjusted to $5 \mathrm{ml}$ with water. To each flask was added $1 \mathrm{~mL}$ each of bromate-bromide solution $\left(10 \mu \mathrm{g} \mathrm{mL}^{-1}\right.$ w. r. t. $\left.\mathrm{KBrO}_{3}\right)$ and $5 \mathrm{~mol} \mathrm{~L}^{-1}$ hydrochloric acid. The flasks were stoppered, contents mixed well and let stand for $15 \mathrm{~min}$ with occasional shaking. Then $1 \mathrm{~mL}$ of $50 \mu \mathrm{g} \mathrm{mL}^{-1}$ methyl orange solution was added to each flask and diluted to the mark with water. The absorbance of each solution was measured at $520 \mathrm{~nm}$ against a reagent blank after $10 \mathrm{~min}$.

Spectrophotometry with indigo carmine (Method C). Varying aliquots of standard AST solution $(0.5-5.0 \mathrm{~mL} ; 25$ $\mu \mathrm{g} \mathrm{mL}^{-1}$ ) were transferred into a series of $10 \mathrm{~mL}$ calibrated flasks by means of a micro burette, and the total volume was brought to $5 \mathrm{~mL}$ by adding water. Accurately measured $1.5 \mathrm{~mL}$ of bromate-bromide solution $\left(30 \mu \mathrm{g} \mathrm{mL}{ }^{-1}\right.$ w.r.t. $\mathrm{KBrO}_{3}$ ) was added to each flask followed by $1 \mathrm{~mL}$ of $5 \mathrm{~mol}$ $\mathrm{L}^{-1}$ hydrochloric acid. The flasks were stoppered, contents mixed and allowed to stand for $15 \mathrm{~min}$ with occasional shaking. Then, $1 \mathrm{~mL}$ of $200 \mu \mathrm{g} \mathrm{mL}^{-1}$ indigo carmine solution was added to each flask and diluted to the mark with water. The absorbance was measured at $610 \mathrm{~nm}$ against a reagent blank after $10 \mathrm{~min}$.

In Methods B and C, a calibration graph was prepared by plotting absorbance versus concentration of drug and the concentration of the unknown was read from the calibration graph or computed from the regression equation derived from the Beer's law data.

\section{Analysis of dosage forms}

An amount of powdered tablets or syrup equivalent to $100 \mathrm{mg}$ of AST was extracted with chloroform $(4 \times 10 \mathrm{~mL})$, the combined extracts were evaporated on a steam bath and the residue was treated as for preparation of standard drug solution. A convenient aliquot was then subject to analysis by either method.

\section{Results and Discussion}

The determination of AST is based on bromination reaction by bromine generated in situ by the action of acid on bromate-bromide mixture. In titrimetry, the reaction is followed by back titration of the residual bromine iodometrically and in spectrophotometry it is followed by change in absorbance of red colour of methyl orange at 520 $\mathrm{nm}$ or blue colour of indigo carmine at $610 \mathrm{~nm}$, the change being caused by the bleaching action of bromine on the dyes.

\section{Method development}

Titrimetry. The quantitative nature of the reaction between AST and in situ generated bromine was checked by treating 4-16 mg of AST with a measured excess of bromate-bromide mixture in acid medium and determining the surplus bromine iodometrically. In the range studied (4-16 mg), the reaction stoichiometry was found to be 1:0.666 ( $\mathrm{AST}: \mathrm{BrO}_{3}^{-}$) which can be represented by the scheme shown in Figure 1.

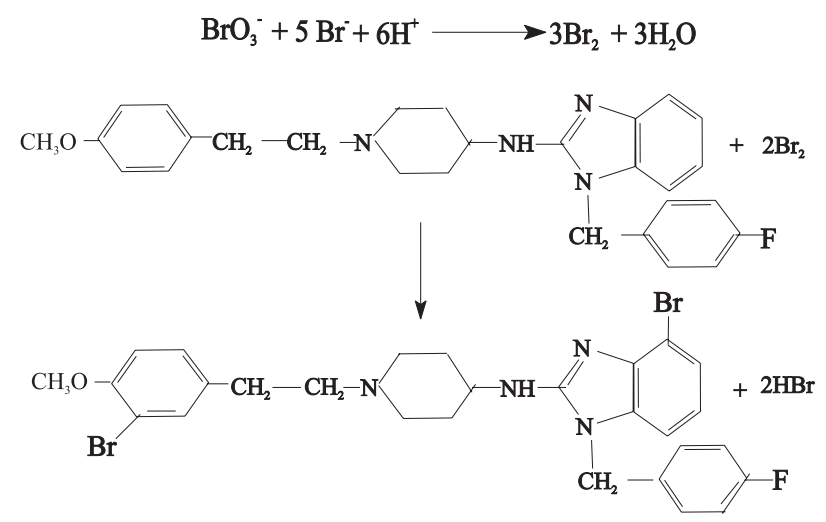

Figure 1. Scheme of bromination reaction. 
The reaction stoichiometry was found to be unaffected in the presence of $4-10 \mathrm{~mL}$ of $2 \mathrm{~mol} \mathrm{~L}^{-1} \mathrm{HCl}$ in a total volume of $24-30 \mathrm{~mL}$, and $7 \mathrm{~mL}$ was chosen as the optimum volume. The bromination reaction was found to be complete in $15 \mathrm{~min}$ and contact time up to $30 \mathrm{~min}$ had no effect on the stoichiometry or the results. A $10 \mathrm{~mL}$ volume of $5 \mathrm{mmol} \mathrm{L}^{-1}$ bromate solution in the presence of a large amount of bromide was found adequate for quantitative bromination of AST in the range investigated. The relation between the amount of drug and titration end point was examined. The linearity is apparent from the calculated correlation coefficient of -0.9962 suggesting that the reaction between AST and bromate proceeds stoichiometrically in the ratio 1:0.666.

Spectrophotometry. Many dyes are irreversibly destroyed to colourless products by oxidizing agents in acid medium ${ }^{27}$ and this observation has been exploited for the indirect spectrophotometric determination of some bioactive compounds. ${ }^{28-32}$ In recent years, acidified solution of bromate and bromide and dyes have been adapted to the quantification of several pharmaceutical substances. ${ }^{19-25}$ In the proposed spectrophotometric methods, the ability of bromine to cause bromination of AST and irreversibly destroy methyl orange and indigo carmine dyes to colourless products in acid medium has been used. Both spectrophotometric methods are based on the bromination of AST by a measured excess of in situ generated bromine and subsequent determination of the unreacted bromine by treating with methyl orange or indigo carmine and measuring the absorbance at $520 \mathrm{~nm}$ or $610 \mathrm{~nm}$. In either method, the absorbance increased linearly with increasing concentration of AST.

AST, when added in increasing concentrations to a fixed concentration of in situ generated bromine, consumes the latter and there will be a concomitant decrease in its concentration. When a fixed concentration of either dye is added to decreasing concentrations of bromine, a concomitant increase in the concentration of dye is obtained. This is observed as a proportional increase in absorbance at the respective $\lambda_{\max }$ with increasing concentration of AST (Figure 2 and 3).

Preliminary experiments were performed to fix the upper limits of the dye concentrations that could be measured spectrophotometrically, and these were found to be $5 \mu \mathrm{g} \mathrm{mL}^{-1}$ and $20 \mu \mathrm{g} \mathrm{mL}^{-1}$ for methyl orange and indigo carmine, respectively. A bromate concentration of $1.0 \mu \mathrm{g} \mathrm{mL}^{-1}$ was found to irreversibly destroy the red colour of $5 \mu \mathrm{g} \mathrm{mL} L^{-1}$ methyl orange whereas $4.5 \mu \mathrm{g} \mathrm{mL}^{-1}$ oxidant was required to bleach the blue colour due to $20 \mu \mathrm{g} \mathrm{mL}^{-1}$ indigo carmine in acid medium. Hence, different amounts of AST were reacted with $1.0 \mathrm{~mL}$ of $10 \mu \mathrm{g} \mathrm{mL}^{-1}$ bromate in

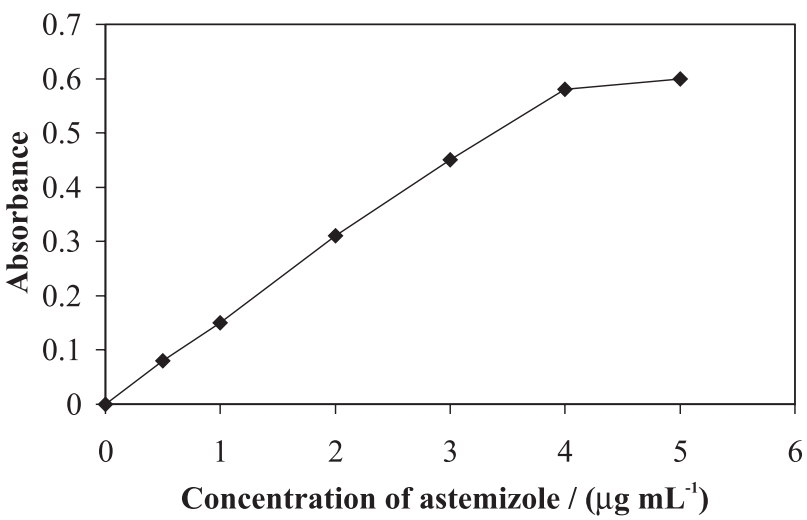

Figure 2. Beer's law curve for Method B.

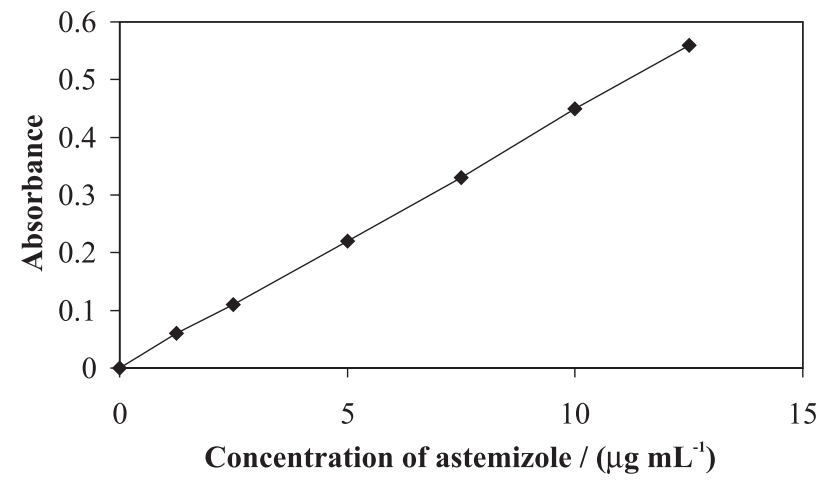

Figure 3. Beer's law curve for Method C.

Method B and $1.5 \mathrm{~mL}$ of $30 \mu \mathrm{g} \mathrm{mL}^{-1}$ oxidant in Method $\mathrm{C}$ in the presence large excess of bromide and in acid medium followed by the determination of the residual bromine as described under the respective procedures.

Hydrochloric acid was the medium of choice for the bromination of AST by bromine as well as the latter's determination employing the dyes. The absorbance of the dyes was not affected in $0.125-1.25 \mathrm{~mol} \mathrm{~L}^{-1}$ hydrochloric acid concentration. However, since $1 \mathrm{~mL}$ of $5 \mathrm{~mol} \mathrm{~L}^{-1}$ acid in a total volume of about $7 \mathrm{~mL}$ was found sufficient to cause bromination of drug in a reasonable time of $15 \mathrm{~min}$, the same concentration $\left(0.5 \mathrm{~mol} \mathrm{~L}^{-1}\right)$ was maintained for the determination of unreacted bromine with the dyes. The specified acid concentration for bromination reaction was found not critical. The bromination reaction was found to be complete in $15 \mathrm{~min}$ and contact times up to $30 \mathrm{~min}$ had no effect on the absorbance of the dyes. A contact time of 5 min was necessary for the bleaching of the dye colour by the residual bromine. The absorbance of either dye solution even in the presence of the brominated drug product was found to be stable for several days.

Analytical parameters. A linear relation was found between absorbance at $\lambda_{\text {max }}$ and concentration ranges given in Table 1. Correlation coefficients, intercepts and slopes for 
the calibration graphs are also presented in Table 1. Sensitivity parameters such as molar absorptivity, detection limit and quantification limit are also compiled in Table 1 and indicate the high sensitivity of the spectrophotometric methods.

Table 1. Analytical parameters of spectrophotometric methods

\begin{tabular}{lcc}
\hline Parameters & Method B & Method C \\
\hline$\lambda_{\max }(\mathrm{nm})$ & 520 & 610 \\
Beer's law limits & $0.5-4.0$ & $1.25-12.5$ \\
$\left(\mu \mathrm{g} \mathrm{mL}^{-1}\right)$ & & $2.1 \times 10^{4}$ \\
$\begin{array}{l}\text { Molar absorptivity } \\
\left(\mathrm{L} \mathrm{moL} \mathrm{m}^{-1}\right)\end{array}$ & $6.6 \times 10^{4}$ & 0.18 \\
$\begin{array}{l}\text { Limit of detection } \\
\left(\mu \mathrm{g} \mathrm{mL}^{-1}\right)\end{array}$ & 0.11 & 0.60 \\
$\begin{array}{l}\text { Limit of quantification } \\
\left(\mu \mathrm{g} \mathrm{mL} \mathrm{m}^{-1}\right)\end{array}$ & 0.38 & \\
$\begin{array}{l}\text { Regression equation* } \mathrm{Y}=\mathrm{a}+\mathrm{bX} \\
\text { Slope (b) }\end{array}$ & 0.14 & 0.05 \\
$\begin{array}{l}\text { Intercept (a) } \\
\text { Correlation coefficient }(\mathrm{r})\end{array}$ & 0.9953 & -0.014 \\
\hline
\end{tabular}

$* \mathrm{Y}$ is the absorbance and $\mathrm{X}$ concentration in $\mu \mathrm{g} \mathrm{mL}^{-1}$.

\section{Method validation}

Accuracy and precision. The accuracy of the methods was established by analysing the pure drug at three levels (within the working limits) and the precision was ascertained by calculating the relative standard deviation (RSD) of seven replicate determinations on the same solution containing the drug at three levels. The relative error (\%) and RSD (\%) values which are less than $2 \%$ are indicative of good accuracy and precision of the methods (Table 2). For a better picture of reproducibility on a dayto-day basis, a series was run in which standard drug solution at three levels was determined each day for 5 days, preparing all the solutions afresh. The day-to-day RSD values were less than $3 \%$ and represent the best appraisal of the procedures in daily use.

Application. In India 8 brands of tablets in $10 \mathrm{mg}$ doses and 3 brands of syrups in $5 \mathrm{mg} / 5 \mathrm{~mL}$ doses are commercially available. The proposed methods were applied to the assay of AST in two brands of tablets and two brands of syrups. The results are compiled in Table 3 and were checked by an established UV spectrophotometric method $^{7}$ for comparision. There is a close agreement between the results obtained by the proposed and the reference methods as found from the Student's tand F- values at the $95 \%$ confidence level. The results obtained by the proposed methods also agreed well with the label claim in all instances.

Table 2. Evaluation of accuracy and precision of methods

\begin{tabular}{|c|c|c|c|c|c|c|c|c|c|c|c|c|c|c|}
\hline \multicolumn{5}{|c|}{ Method A } & \multicolumn{5}{|c|}{ Method B } & \multicolumn{5}{|c|}{ Method C } \\
\hline $\begin{array}{c}\text { Amount } \\
\text { taken } \\
(\mu \mathrm{g})\end{array}$ & $\begin{array}{l}\text { Amount } \\
\text { found } * \\
(\mu \mathrm{g})\end{array}$ & $\begin{array}{c}\text { Range } \\
(\mu \mathrm{g})\end{array}$ & $\begin{array}{c}\text { Relative } \\
\text { error } \\
(\%)\end{array}$ & $\begin{array}{l}\text { RSD } \\
(\%)\end{array}$ & $\begin{array}{c}\text { Amount } \\
\text { taken } \\
(\mu \mathrm{g})\end{array}$ & $\begin{array}{l}\text { Amount } \\
\text { found* } \\
(\mu \mathrm{g})\end{array}$ & $\begin{array}{c}\text { Range } \\
(\mu \mathrm{g})\end{array}$ & $\begin{array}{c}\text { Relative } \\
\text { error } \\
(\%)\end{array}$ & $\begin{array}{l}\text { RSD } \\
(\%)\end{array}$ & $\begin{array}{c}\text { Amount } \\
\text { taken } \\
(\mu \mathrm{g})\end{array}$ & $\begin{array}{l}\text { Amount } \\
\text { found* } \\
(\mu \mathrm{g})\end{array}$ & $\begin{array}{c}\text { Range } \\
(\mu \mathrm{g})\end{array}$ & $\begin{array}{c}\text { Relative } \\
\text { error } \\
(\%)\end{array}$ & $\begin{array}{l}\text { RSD } \\
(\%)\end{array}$ \\
\hline 4.0 & 4.09 & 0.35 & 2.25 & 1.62 & 10.0 & 9.83 & 0.71 & 1.72 & 3.51 & 25.0 & 25.55 & 0.50 & 2.20 & 2.02 \\
\hline 8.0 & 8.15 & 0.52 & 1.87 & 1.89 & 20.0 & 20.50 & 0.70 & 2.50 & 1.74 & 50.0 & 50.80 & 0.60 & 1.60 & 0.82 \\
\hline 12.0 & 12.16 & 0.15 & 1.33 & 1.21 & 30.0 & 30.70 & 0.70 & 2.33 & 1.24 & 100.0 & 97.69 & 0.40 & 2.31 & 1.09 \\
\hline
\end{tabular}

* Mean value of seven determinations.

Table 3. Results of assay of formulations by the proposed methods

\begin{tabular}{|c|c|c|c|c|c|}
\hline \multirow{2}{*}{$\begin{array}{l}\text { Formulation } \\
\text { brandname }\end{array}$} & \multirow{2}{*}{$\begin{array}{c}\text { Nominal } \\
\text { amount } \\
\text { (mg/tablet } \\
\text { or } \mathrm{mg} / \mathrm{mL})\end{array}$} & \multicolumn{4}{|c|}{ Found $^{\mathrm{a}} \pm \mathrm{SD}(\%)$} \\
\hline & & Method A & Method B & Method C & Reference method \\
\hline \multirow[t]{2}{*}{ Acemiz tablets ${ }^{c}$} & & $99.44 \pm 0.86$ & $100.7 \pm 1.32$ & $98.16 \pm 1.04$ & \\
\hline & 10.0 & $\begin{array}{c}\mathrm{t}=1.11 \\
\mathrm{~F}=1.43\end{array}$ & $\begin{array}{c}\mathrm{t}=2.51 \\
\mathrm{~F}=3.36\end{array}$ & $\begin{array}{l}\mathrm{t}=0.45 \\
\mathrm{~F}=2.09\end{array}$ & $98.56 \pm 0.72$ \\
\hline \multirow[t]{2}{*}{ Acemiz syrup ${ }^{c}$} & 1.0 & $102.6 \pm 1.44$ & $100.9 \pm 1.77$ & $101.8 \pm 0.72$ & \\
\hline & & $\begin{array}{l}\mathrm{t}=1.22 \\
\mathrm{~F}=2.25\end{array}$ & $\begin{aligned} t & =0.59 \\
F & =3.40\end{aligned}$ & $\begin{array}{c}\mathrm{t}=0.69 \\
\mathrm{~F}=1.78\end{array}$ & $101.2 \pm 0.96$ \\
\hline \multirow[t]{2}{*}{ Histeese Tablets $^{\mathrm{d}}$} & 10.0 & $98.28 \pm 0.54$ & $97.96 \pm 1.24$ & $98.26 \pm 1.86$ & \\
\hline & & $\begin{array}{l}\mathrm{t}=1.29 \\
\mathrm{~F}=5.44\end{array}$ & $\begin{aligned} \mathrm{t} & =1.18 \\
\mathrm{~F} & =1.03\end{aligned}$ & $\begin{array}{l}t=0.76 \\
F=2.18\end{array}$ & $99.44 \pm 1.26$ \\
\hline Histeese syrup ${ }^{d}$ & 1.0 & $\begin{array}{c}102.4 \pm 1.78 \\
t=0.84 \\
F=4.09\end{array}$ & $\begin{array}{c}101.7 \pm 1.63 \\
t=1.45 \\
F=3.43\end{array}$ & $\begin{array}{c}102.9 \pm 1.42 \\
t=0.55 \\
F=2.60\end{array}$ & $103.5 \pm 0.88$ \\
\hline
\end{tabular}

${ }^{a}$ Mean value of five determinations; ${ }^{b}$ Marketed by: ${ }^{\mathrm{c}}$ Lupin Lab. Ltd.; ${ }^{\mathrm{d}}$ Micro Labs.; Tabulated t-value at $95 \%$ confidence level is 2.77 ; Tabulated F-value at $95 \%$ confidence level is 6.39 . 
The accuracy and reliability of the methods were further established by performing recovery studies. To a fixed amount of drug in dosage forms (pre-analyzed) pure AST was added at three levels and the total was found by the proposed methods. Each test was performed three times. The recovery of pure AST added to formulations ranged from 96.52 - $104.46 \%$ indicating that commonly encountered excipients and additives did not interfere in the methods.

\section{Conclusions}

Three useful methods for the determination of astemizole using bromate-bromide mixture, and methyl orange and indigo carmine have been developed and validated according to ICH guidelines. The titrimetric method is simple to perform unlike the previously reported method ${ }^{6}$ which requires a non aqueous medium and has a narrow range of applicability. The spectrophotometric methods are also easier and cheaper to perform compared to many existing methods and are free from heating or extraction step. The proposed methods do not entail any stringent experimental variables which affect the reliability of results. The spectrophotometric methods have a higher sensitivity than the existing methods. The ingredients usually present in the pharmaceutical formulations of astemizole do not interfere in the proposed methods. The methods thus can be used in the routine determination of astemizole in pure form and in dosage forms.

\section{Acknowledgements}

The authors gratefully acknowledge the receipt of pure astemizole from UCB India Ltd, Mumbai, India as gift. One of the authors (PN) thanks the authorities of the University of Mysore, Mysore for research facilities.

\section{References}

1. Al-Obaid, A. M.; Mian, M. S. In Analytical Profiles of Drug Substances; Florey, K., ed.; Academic Press: New York, 1991, p. 173.

2. Morton, I. K. M.; Hall, J. M.; Halliday, J.; Graham, H.; Medicines. The Comprehensive Guide, Bloomsbury: London, 1991.

3. Mangalan, S.; Patel, R. B.; Gandhi, T. P.; Chakravarthy, B. K.; J. Chromatogr. Biomed. Appl. 1991, 105, 498.

4. Woestenborghs, R.; Embrechts, L.; Heykants, J.; J. Chromatogr. Biomed. Appl. 1983, 29, 359.
5. Woestenborghs, R.; Geuens, I.; Michiels, M.; Hendriks, R.; Heykants, J.; Drug Dev. Ind. Pharm. 1986, 8, 63.

6. Sane, R.T.; Purohit, A. K.; Sodhi, R. A.; Singh, S. R.; Indian Drugs 1993, 30, 156.

7. Gungor, S.; Onur, F.; J. Pharm. Biomed. Anal. 2001, 25, 511.

8. Mabrouk, M. M.; Egypt. J. Biomed. Sci. 1998, 1, 13.

9. Sadana, G. S.; Potdar, A.; J. Indian Drugs 1989, 27, 140.

10. Basavaiah, K.; Charan, V. S.; Chandrashekar, U.; Indian J. Chem. Technol. 2004, 11, 61.

11. Karam, H.; El-Kousy, N.; Towakkol, M.; Anal. Lett. 1999, 32, 79.

12. Sastry, C. S. P.; Naidu, P.Y.; Talanta 1998, 45, 795.

13. Sastry, C. S. P.; Naidu, P.Y.; Indian Drugs 1997, 34, 140.

14. Alwarthan, A. A.; Al-Obaid, A. M.; J. Pharm. Biomed. Anal. 1996, 14, 579.

15. Daabees, H.G.; Spectroscop. Lett. 1999, 32, 913.

16. Cetin, S. M.; Tosunoglu, S.; Pharm. Turc. 2001, 45, 65.

17. Basavaiah, K.; Charan, V. S.; Sci. Asia 2002, 28, 359.

18. Kelani, K.; Bebawy, L. I.; Abdel-Fattah, L.; J. Pharm. Biomed. Anal. 1999, 18, 985.

19. Basavaiah, K.; Prameela, H. C.; Oxid. Commun. 2004, 27, 177

20. Basavaiah, K.; Prameela, H. C.; Anal. Bioanal. Chem. 2003, 376, 879.

21. Basavaiah, K.; Nagegowda, P.; Oxid. Commun. 2004, 27, 186

22. Basavaiah, K.; Chandrashekar, U.; Prameela, H. C.; Nagegowda, P.; Acta Cien. Indica Chem. 2003, 29, 25.

23. Basavaiah, K.; Prameela, H. C.; Sci. Asia 2003, 29, 147.

24. Basavaiah, K.; Nagegowda, P.; J. Saudi Chem. Soc. 2004, 8, 11

25. Basavaiah, K.; Nagegowda, P.; Il Farmaco 2004, 59, 147.

26. Bassett, J.; Denny, R. C.; Jeffery, G. H.; Mendham, J.; Vogel's Text Book of Quantitative Inorganic Analysis, $4^{\text {th }}$ ed., Longman Group Ltd.: London, 1978, p. 376

27. Kolthoff, I. M.; Belcher, R.; Stenger, V. A.; Matsuyana, G. E.; Volumetric Analysis, $1^{\text {st }}$ ed., Interscience Publishers Inc: New York, 1957, vol. III, p. 501.

28. Sharma, C.S.N.; Kamala Sastry, C.; Sastry, C. S. P.; Acta Cien. India Chem. 2002, 28, 221.

29. Sastry, C. S. P.; Lingeswara Rao, J. S. V. M.; East Pharm. 1996, 39, 117.

30. Sastry, C. S. P.; Sharma, V. A. N.; Prasad, U.V.; Lakshmi, C. S. R.; Indian J. Chem. Soc. 1997, 59, 161.

31. Basavaiah, K.; Prameela, H. C.; Anal. Sci. 2003, 19, 779.

32. Sastry, C. S. P.; Gopala Rao, G.; Naidu, P.Y.; Anal. Lett. 1998, $31,263$.

Received: July 28, 2004

Published on the web: June 09, 2005 